\title{
WELCOME TO CONFERENCE PARTICIPANTS
}

Herbert E. Doig, Assistant Commissioner for Natural Resources, NY State Dept. of Environmental

Conservation, 50 Wolf Road, Albany, NY 12233

It is a pleasure for me to welcome participants of the First Eastern Wildlife Damage Control Conference and I bring you greetings and best wishes for a successful conference from Governor Mario Cuomo and commissioner of Environmental Conservation Henry Williams. It is appropriate that the first conference on this important subject in the East be held in New York since we typify a variety of interactions between people and wildlife that are characteristic of the region

A number of situations bring us here. Agriculture has long absorbed the cost of wildlife damage to crops; perhaps the most common being that caused by deer. But farmers are not alone in having to deal with activities of wildlife. Housewives must cope with skunks under the porch; environmentalists worry about bird mortality from unknown causes; agency people must resolve conflicts between fish hatchery and game farm production and great blue herons and a variety of hawks, and families often experience marauding black bears in their campsites. From elephants to water snakes, the conflicts between people and wildlife are a continuing problem. This variety of issues emphasizes the need for resource scientists to develop imaginative responses that will be sensitive to both human and resource needs.

We, in New York, recognize the mandate to assure a balanced interaction between wildlife and people and have appropriately expressed this concern in one of the fish and wildlife program's primary goals: i.e., to manage fish and wild life resources so that their numbers and occurrence are compatible with habitat capability and the public interest. We view our role not as a welfare agency where government will be all things to all people and not as a vendor paying for all damages, but rather as an advisor to assist people in finding solutions to problems brought about by this publicly owned resource. In some instances, direct governmental involvement is appropriate, especially where high value resources are involved or where wildlife are considered rare or endangered.

Citizens then have the primary responsibility for responding to wildlife damage and they need help.

The colleges play a role as well, developing new animal control techniques and sharing those techniques and others, that are commonly used, with people.
Private enterprise has also risen to the challenge and we see animal control capability growing in companies heretofore specializing in insect pest control activities. Trappers too have become involved, training landowners to handle individual and specific wildlife nuisance problems or often giving their time and experience to become actively involved.

There is no question then that this conference is needed and that it represents a giant step toward sharing of knowledge. More importantly, each of you will leave here with a better understanding of what is not known so that future priorities for research may focus on these needs.

We in the Department are pleased to be a cooperator with the College of Agriculture and Life Sciences and the College of Environmental Science and Forestry in making this conference a reality. We hope that it will be a beginning in a renewed effort to better serve the public and wildlife resources in the future 